\title{
CHANGE OF DIET OF THE GREENLAND VIKINGS DETERMINED FROM STABLE CARBON ISOTOPE ANALYSIS AND ${ }^{14} \mathrm{C}$ DATING OF THEIR BONES
}

\author{
Jette Arneborg ${ }^{1} \bullet$ Jan Heinemeier $^{2} \bullet$ Niels Lynnerup $^{3} \bullet$ Henrik L Nielsen ${ }^{2} \bullet$ Niels Rud $^{2} \bullet$ \\ Árný E Sveinbjörnsdóttir ${ }^{4}$
}

\begin{abstract}
Bone samples from the Greenland Viking colony provide us with a unique opportunity to test and use ${ }^{14} \mathrm{C}$ dating of remains of humans who depended upon food of mixed marine and terrestrial origin. We investigated the skeletons of 27 Greenland Norse people excavated from churchyard burials from the late 10th to the middle 15 th century. The stable carbon isotopic composition $\left(\delta^{13} \mathrm{C}\right)$ of the bone collagen reveals that the diet of the Greenland Norse changed dramatically from predominantly terrestrial food at the time of Eric the Red around AD 1000 to predominantly marine food toward the end of the settlement period around $\mathrm{AD} 1450$. We find that it is possible to ${ }^{14} \mathrm{C}$-date these bones of mixed marine and terrestrial origin precisely when proper correction for the marine reservoir effect (the ${ }^{14} \mathrm{C}$ age difference between terrestrial and marine organisms) is taken into account. From the dietary information obtained via the $\delta^{13} \mathrm{C}$ values of the bones we have calculated individual reservoir age corrections for the measured ${ }^{14} \mathrm{C}$ ages of each skeleton. The reservoir age corrections were calibrated by comparing the ${ }^{14} \mathrm{C}$ dates of 3 highly marine skeletons with the ${ }^{14} \mathrm{C}$ dates of their terrestrial grave clothes. The calibrated ages of all 27 skeletons from different parts of the Norse settlement obtained by this method are found to be consistent with available historical and archaeological chronology. The evidence for a change in subsistence from terrestrial to marine food is an important clue to the old puzzle of the disappearance of the Greenland Norse, obtained here for the first time by measurements on the remains of the people themselves instead of by more indirect methods like kitchen-midden analysis.
\end{abstract}

\section{INTRODUCTION}

\section{Bone Dating}

The ${ }^{14} \mathrm{C}$ dating of bone is by now technically well established, relying on refined chemical extraction techniques combined with accelerator mass spectrometry (AMS) (for example, Brown et al. 1988). Since very small, even submilligram-sized, samples of bone collagen can be dated with AMS, it has become possible to select the best samples from a skeleton, minimizing problems with degradation and contamination. If the bone is reasonably well preserved, AMS ${ }^{14} \mathrm{C}$ ages as well as stable carbon isotopic ratios can be determined reliably for skeletal remains of archaeological interest without destroying the object. If the bone collagen is of terrestrial origin, the measured (conventional) ${ }^{14} \mathrm{C}$ age is converted into a true calendar age by using the global tree-ring calibration curve (Stuiver and Polach 1977). However, this simple procedure is not applicable when the bone collagen is derived in part from marine carbon which, due to the marine reservoir effect, appears several hundred ${ }^{14} \mathrm{C}$ years older than the corresponding terrestrial carbon. This seriously constrains the dating of bones of people who have had access to food protein from the sea. Therefore, archaeologists have generally distrusted the precision of ${ }^{14} \mathrm{C}$ dates of human bones. But precise ${ }^{14} \mathrm{C}$ dating of human bones is so attractive to the archaeologist that it is highly desirable to add bone to the list of datable material. To extend the calibration of measured ${ }^{14} \mathrm{C}$ ages to "marine" bones one needs to know both the marine food fraction and the reservoir age, that is, the age difference between the atmosphere and the particular region of the sea at the time the protein was produced.

\section{Carbon Isotope Fractionation and Diet}

Previous investigations have shown that $\delta^{13} \mathrm{C}$ of bone collagen can be used as an indicator of food composition $\left(\delta^{13} \mathrm{C}\right.$ is the fractional deviation of the ${ }^{13} \mathrm{C} /{ }^{12} \mathrm{C}$ ratio from the VPDB standard). The

\footnotetext{
${ }^{1}$ Department of Prehistory and the Middle Ages, The National Museum of Denmark, DK-1220 Copenhagen, Denmark

${ }^{2}$ Institute of Physics and Astronomy, University of Aarhus, DK-8000 Aarhus, Denmark

${ }^{3}$ Laboratory of Biological Anthropology, The Panum Institute, University of Copenhagen, DK-2000 Copenhagen, Denmark

${ }^{4}$ Science Institute, University of Iceland, IS-107 Reykjavik, Iceland
} 
composition determined may be either the relative components of marine/terrestrial food protein (Tauber 1981; Chisholm et al. 1982; Johansen et al. 1986) or plants of $C_{3}$ and $C_{4}$ photosynthesis (e.g., van der Merwe and Vogel 1978; van der Merwe 1982) and according to some authors (Chisholm et al. 1982; Lovell et al. 1986; Chisholm et al. 1983; Heinemeier and Rud 1997), the marine food fractions can even be deduced with reasonable precision $( \pm 10 \%)$ via $\delta^{13} \mathrm{C}$ measurements of bone collagen for individuals in a human population. The data compiled in Table 1 are for population groups from high northern latitudes where the $\delta^{13} \mathrm{C}$ signal provides a sharp distinction between marine and terrestrial food, since $\mathrm{C}_{4}$ plants (with a different photosynthetic pathway and isotopic fractionation [Lovell et al. 1986]) are not present in these areas. The $\delta^{13} \mathrm{C}$ distribution for a single population group can be extremely narrow (standard deviation about $0.3 \%$, just a few times the measuring uncertainty) (Table 1). This means that the variability in metabolic isotope fractionation among individuals is negligible. Hence we conclude that differences in $\delta^{13} \mathrm{C}$ of human bone collagen from high latitudes must reflect real differences in the average diet consumed by the individual over roughly 10 years, which represents the collagen turnover time in human bone.

Table 1 Bone collagen $\delta^{13} \mathrm{C}$ values for population groups from northern regions

\begin{tabular}{lllrcc}
\hline Locality & Period & Type & $\mathrm{N}$ & $\begin{array}{c}\delta^{13} \mathrm{C} \% 0 \\
(\text { VPDB })\end{array}$ & $\begin{array}{c}\text { Percent } \\
\text { marine diet }\end{array}$ \\
\hline Tuna, Sweden $^{\mathrm{a}}$ & Viking age & Inland & 7 & $-20.49 \pm 0.26$ & 6 \\
Leksand I, Sweden $^{\mathrm{a}}$ & Medieval & Inland & 11 & $-20.92 \pm 0.36$ & 1 \\
Leksand II, Sweden $^{\mathrm{a}}$ & 17th century & Inland & 10 & $-20.69 \pm 0.33$ & 4 \\
Heidal, Norway $^{\mathrm{a}}$ & Medieval & Inland & 10 & $-20.6 \pm 0.3$ & 5 \\
Saskatchewan, Canada $^{\mathrm{b}}$ & Prehistoric & Inland & 50 & $-17.5 \pm 0.3$ & $-{ }^{\mathrm{b}}$ \\
British Columbia, Canada $^{\mathrm{c}}$ & Prehistoric & Coastal & 37 & $-13.3 \pm 0.4$ & 91 \\
West Greenland, Eskimos $^{\mathrm{d}}$ & 15th century & Coastal & 8 & $-12.49 \pm 0.18$ & 100 \\
\hline
\end{tabular}

$\mathrm{N}$ is number of individuals in the population group. $\delta^{13} \mathrm{C}$ is the relative deviation of the ${ }^{13} \mathrm{C} /{ }^{12} \mathrm{C}$ isotopic ratio from the VPDB standard. The variabilities in the $\delta^{13} \mathrm{C}$ values are one standard deviation. Percent marine diet is calculated from $\delta^{13} \mathrm{C}$ by linear interpolation between the $\delta^{13} \mathrm{C}$ values $-12.5 \%$ and $-21 \%$, taken to be the endpoint values for purely marine and purely terrestrial (pure $\mathrm{C}_{3}$ ) diet respectively.

${ }^{a}$ These data are for inland populations from Sweden (Lidén and Nelson 1994) and Norway (Johansen et al. 1986) known to have negligible access to marine food.

${ }^{\mathrm{b}}$ The less negative $\delta^{13} \mathrm{C}$ average for this inland population is ascribed to admixtures of $\mathrm{C}_{4}$ plants in diet (Lovell et al. 1986). ${ }^{c}$ Chisholm et al. 1983.

${ }_{\mathrm{d}}^{\mathrm{d}}$ This West Greenland Eskimo population were close neighbors to the Norse (Heinemeier and Rud 1997). The $\delta^{13} \mathrm{C}$ average is identical to our choice of endpoint value for $100 \%$ marine food.

All inland sites where $\mathrm{C}_{3}$ plants compose local vegetation, such as in Greenland and Scandinavia, show narrow $\delta^{13} \mathrm{C}$ distributions without significant difference in absolute values (Table 1). This is consistent with the geographically and archaeologically expected well-defined (terrestrial) food pattern and leads us to adopt the endpoint $\delta^{13} \mathrm{C}$ value of $-21 \%$ or a $100 \%$ terrestrial diet. The marine endpoint value is more difficult to establish, as no human population a priori can be expected to have a $100 \%$ marine diet. This is probably reflected in the scatter and absolute value of the prehistoric British Columbia Indian population, which is archaeologically expected to have had a dominantly marine food pattern, but probably with a non-negligible (and individually varying) terrestrial component. We have adopted the marine endpoint value $-12.5 \%$ from the results of our previous measurements (Heinemeier and Rud 1997, see Table 1) of a series of Thule Culture Eskimos who lived close to the Norsemen in location and time period (Grummesgaard-Nielsen 1997; Lynnerup et al. 1997). As they are the most "marine" individuals that we are aware of at present, we assume a $100 \%$ 
marine diet, although only future isotopic research (for example, $\delta^{15} \mathrm{~N}$ as an indicator of trophic level) can reveal whether a significant terrestrial (e.g., reindeer) diet component was present. In any case, the known, extremely marine, economy of this Eskimo population represents a natural reference for the degree of adaptation of the Greenland Norse to a similar diet pattern. The endpoint values adopted for the present work are close to those suggested by Chisholm (1989). As it turns out, our calibrated ages are rather insensitive to the exact choice of endpoints (see below).

\section{The Greenland Norse}

The aim of the present work was to investigate the potential of using a simple linear interpolation between the endpoint (pure marine versus pure terrestrial) $\delta^{13} \mathrm{C}$ values to 1 ) calculate the marine fraction of each individual, and 2) correct ${ }^{14} \mathrm{C}$ dates of mixed marine material. Our test material is bones of Greenland Norse. The story of the Greenland Norse (Krogh 1967; Jones 1986) began around AD 985, when a group of Icelandic farmers, lead by Eric the Red, colonized Southwest Greenland. Together with other small chieftains, Eric the Red and his household founded the Eastern Settlement (see Figure 1). Another group of settlers went farther north to the area around present Nuuk, where they founded the Western Settlement. The number of Norse people in Greenland is estimated to have peaked at 4000-5000 individuals. For reasons that have been debated for years, their number declined and the settlements were finally abandoned completely, probably in the middle of the 15th century. Present knowledge of the Norse culture in Greenland is based chiefly on the available written sources and the results of archaeological excavations of the remains of farmsteads and churchyards. The excavations indicate that Norse subsistence depended on the products of animal husbandry and seal hunting. However, quantitative information on the diet of the Norse is difficult to obtain from the usual archaeological sources, since the food refuse preserved in farms and the

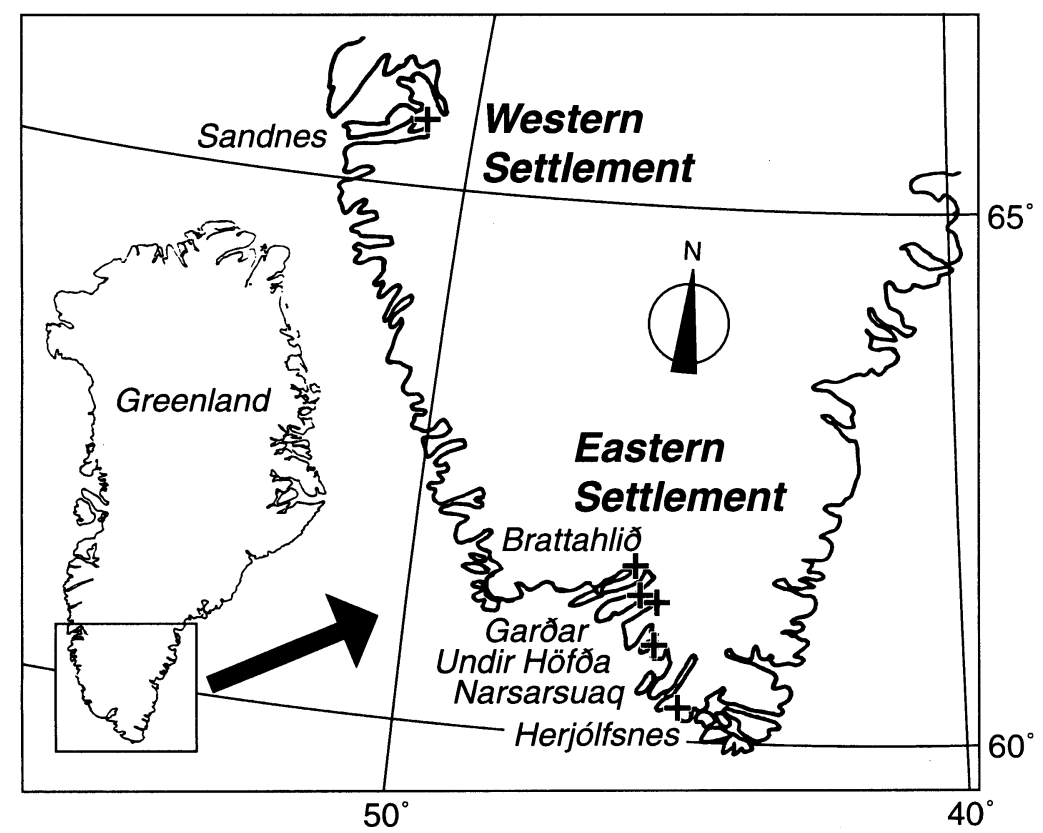

Figure 1 Map showing the location of Norse churchyards in Greenland. Sandnes is in the Western Settlement near Nuuk, the modern capital of Greenland. Five churchyards are in the Eastern Settlement in the southernmost part of Greenland. 
middens may not be truly representative (e.g., Renfrew and Bahn 1991). To throw more light on this aspect of Norse history by establishing the necessary, ${ }^{14} \mathrm{C}$-based, chronology in the absence of other means of dating burials, it was decided to investigate the skeletal remains of the people themselves by carbon isotope analysis. The present research was initiated to help determine the corrections on ${ }^{14} \mathrm{C}$ ages of bone collagen required because of its mixed marine and terrestrial origin of ingested foods.

\section{METHODS AND ANALYSIS}

The ${ }^{14} \mathrm{C}$-dating was carried out on a set of bone samples from 6 Norse churchyards in Southwest Greenland, 5 from the Eastern Settlement and 1 from the Western Settlement (Table 2). The 27 individual bones were selected from about 450 skeletons excavated between 1921 and 1981 by the Danish National Museum and now kept at the Laboratory of Biological Anthropology in Copenhagen. The selection strategy was meant to cover the entire settlement period and provide some geographical variation. Care was taken to choose skeletons from graves with at least some stratigraphic information available or to choose skeletons that had been found in close stratigraphic connection with other datable finds. Unfortunately, grave goods are normally absent in Christian graves, making ${ }^{14} \mathrm{C}$ human bone dating the only means of establishing the ages of the burials, but in several cases, instead of using wooden coffins, the Norse Greenlanders buried their dead wrapped in clothes that could be used as a dating reference. Sex and age of the buried persons were determined when possible.

Samples of bones and textiles were analyzed for ${ }^{14} \mathrm{C}$ and stable carbon isotopes (Table 2). We had to address the question of possible contamination from carbon-containing preservatives. Thus, the textiles from Herjolfsnes may have been treated at the time of excavation with Beticol, an animal collagen glue (Nørlund 1924). This preservative is not expected to cause problems, since it dissolves during pretreatment (A-A-A) with $1 \mathrm{M} \mathrm{HCl}$ at $100{ }^{\circ} \mathrm{C}$ for $10 \mathrm{~min}$. Some of the bones had visible signs (a thin, shiny film) of conservation treatment. Likely preservatives are either white joiner's glue (collagen, typically extracted from horse bone) used during early excavation in Greenland (Hansen 1924) or Bedacryl (a synthetic polymer) used more recently. Prior to chemical pretreatment, the surface of bone samples was removed by scalpel to eliminate contamination and possible preservatives. Bedacryl is insoluble in the collagen extraction process, but the collagen preservative potentially poses a problem. However, we feel confident that the mechanical surface cleaning reduces the possible contamination level to below a few percent. As an example, it would take 5\% contamination and the worst case of a strongly marine influenced bone treated with horse glue to produce a shift in $\delta^{13} \mathrm{C}$ of $-0.4 \%$ and a ${ }^{14} \mathrm{C}$ shift of $50 \mathrm{yr} \mathrm{BP}$ for a very early bone (e.g. Brattahlið) treated with modern (pre-bomb) glue.

Collagen was extracted from 100-200 mg bone samples and combusted to carbon dioxide. We used a modified Longin method (Longin 1971; Brown et al. 1988) with pretreatment consisting of demineralization with $1 \mathrm{M} \mathrm{HCl}$ at $5{ }^{\circ} \mathrm{C}$ for about $30 \mathrm{~min}$, humic acid removal with $0.2 \mathrm{M} \mathrm{NaOH}$, and reflux with $0.01 \mathrm{M} \mathrm{HCl}$ at $70{ }^{\circ} \mathrm{C}$ for $16 \mathrm{~h}$. Nearly all samples had collagen yields of close to $5 \%$ or above, which is a safe limit for reliable dating recommended by Hedges and van Klinken (1992) and others. Only 1 sample was as low as $1 \%$ and therefore rejected for dating. Most of the $\mathrm{CO}_{2}$ was converted to graphite for AMS ${ }^{14} \mathrm{C}$ dating with the EN tandem accelerator at the University of Aarhus, and the rest was used for $\delta^{13} \mathrm{C}$ measurement by conventional mass spectrometry at the Science Institute, University of Iceland (Table 2). Detailed archaeological and anthropological information about the samples may be found in Lynnerup (1998). To improve the accuracy, at least 2 samples were prepared from each bone specimen. All measurements were used (no outliers) and all multiple samples were in agreement within statistical error. Our results for the recent TIRI intercalibration (Gulliksen and Scott 1995) showed that the precision reflects the actual accuracy. 
Table $2{ }^{14} \mathrm{C}$ dates and $\delta^{13} \mathrm{C}$ values for bone collagen and cloth from Norse churchyards in Greenland

\begin{tabular}{|c|c|c|c|c|c|c|c|}
\hline $\begin{array}{c}\text { Lab } \\
\text { number } \\
\text { (AAR-) }\end{array}$ & $\begin{array}{l}\text { Object } \\
\text { ID number }\end{array}$ & $\begin{array}{l}\text { Sample } \\
\text { sex, age }\end{array}$ & $\begin{array}{l}\text { Conventional } \\
{ }^{14} \mathrm{C} \text { age } \\
\text { (yr BP) }\end{array}$ & $\begin{array}{l}\text { Calendar } \\
\text { age } \\
\text { (cal AD) }\end{array}$ & $\begin{array}{c}\text { cal } \mathrm{AD} \\
\text { range, } \\
1 \sigma\end{array}$ & $\begin{array}{c}\delta^{13} \mathrm{C} \\
(\% \circ \text { VPDB })\end{array}$ & $\begin{array}{c}\text { Percent } \\
\text { marine } \\
\text { diet }\end{array}$ \\
\hline \multicolumn{8}{|c|}{ Eastern Settlement } \\
\hline \multicolumn{8}{|c|}{ Herjolfsnes $^{\mathrm{a}}$ (E111, Ikigaat) } \\
\hline 1271 & IV/KAL1106 & $\mathrm{u}, 10-15$ & $767 \pm 45$ & 1430 & $1407-1447$ & -16.3 & 55 \\
\hline 1290 & D10606 & Cloth & $553 \pm 45$ & 1410 & $1330-1428$ & -22.1 & \\
\hline 1269 & XVIII/KAL906 & $\mathrm{F}, 20-25$ & $899 \pm 84$ & 1418 & $1329-1456$ & -14.4 & 78 \\
\hline 1289 & D10605 & Cloth & $480 \pm 43$ & 1434 & $1419-1445$ & -22.3 & \\
\hline 1270 & I/KAL1105 & $\mathrm{F}, 45-50$ & $750 \pm 56$ & 1437 & $1413-1467$ & -16.2 & 57 \\
\hline 1288 & D10581 & Cloth & $480 \pm 60$ & 1434 & $1413-1449$ & -21.8 & \\
\hline 2201 & D10612 & "Burgundy cap" & $685 \pm 40$ & 1300 & $1280-1380$ & -22.6 & \\
\hline 2200 & D10594 & Garment & $650 \pm 40$ & $1305-1375$ & $1295-1395$ & -22.4 & \\
\hline \multicolumn{8}{|c|}{ Brattahlið "Tjodhilde's Church" (E29a, Qassiarsuk) } \\
\hline 1275 & KAL1180 & $\mathrm{M},>35$ & $1229 \pm 41$ & 976 & $894-996$ & -18.5 & 29 \\
\hline 1571 & KAL1054 & F, 25-30 & $1225 \pm 51$ & 985 & $909-1017$ & -18.0 & 35 \\
\hline 1273 & KAL0380 & Ox bone & $1040 \pm 80$ & 1011 & $960-1040$ & -20.6 & \\
\hline 1267 & CLA-2 & M, adult & $1155 \pm 46$ & 1020 & $995-1043$ & -18.1 & 34 \\
\hline 1268 & CLA-1 & M, adult & $1112 \pm 51$ & $1065-1115$ & $1028-1171$ & -17.5 & 41 \\
\hline 1568 & KAL1041 & F, 35-40 & $997 \pm 51$ & 1165 & $1046-1218$ & -19.0 & 24 \\
\hline 1272 & KAL1060 & $\mathrm{F}$, adult & $980 \pm 49$ & 1169 & $1061-1222$ & -19.1 & 22 \\
\hline 1570 & KAL1059 & $\mathrm{F},>35$ & $1092 \pm 55$ & 1172 & $1063-1227$ & -16.8 & 49 \\
\hline 1569 & KAL1043 & F, $35-40$ & $985 \pm 45$ & 1175 & $1061-1226$ & -18.9 & 25 \\
\hline 1276 & KAL1789 & M, 50-55 & $1025 \pm 50$ & 1192 & $1122-1228$ & -18.0 & 35 \\
\hline \multicolumn{8}{|c|}{$\operatorname{Garðar}^{\mathrm{c}}($ E47, Igaliku $)$} \\
\hline 1437 & KAL0915 & M, 30-35 & $1030 \pm 65$ & 1233 & $1170-1281$ & -16.8 & 50 \\
\hline 1439 & KAL1118 & M, adult(B) & $880 \pm 55$ & 1272 & $1223-1290$ & -18.8 & 25 \\
\hline 1438 & KAL0916 & $\mathrm{F}$, adult & $880 \pm 90$ & 1295 & $1256-1392$ & -17.6 & 40 \\
\hline \multicolumn{8}{|c|}{ Undir Höfða ${ }^{\mathrm{d}}($ E66, Igaliku kuljalleq) } \\
\hline 1442 & KAL0920 & M, 30-35 & $890 \pm 45$ & 1297 & $1279-1317$ & -17.3 & 44 \\
\hline 1441 & KAL0919 & $F, 25-30$ & $880 \pm 55$ & 1392 & $1312-1417$ & -15.8 & 61 \\
\hline \multicolumn{8}{|c|}{ Convent $^{\mathrm{e}}$ (E 149, Narsarsuaq) } \\
\hline 1265 & II,1/KAL1002 & $F, 35-40$ & $886 \pm 48$ & 1322 & $1301-1399$ & -16.3 & 55 \\
\hline 1264 & I,10/KAL1001 & M, adult & $937 \pm 53$ & 1389 & $1312-1414$ & -14.8 & 73 \\
\hline 1266 & I,6/KAL0999 & $\mathrm{u}, 15-20$ & $852 \pm 44$ & 1399 & $1325-1418$ & -16.0 & 59 \\
\hline 1263 & I,7/KAL1000 & M, 25-30 & $845 \pm 50$ & 1404 & $1329-1428$ & -15.9 & 60 \\
\hline \multicolumn{8}{|c|}{ Western Settlement } \\
\hline \multicolumn{8}{|c|}{ Sandnes $^{\mathrm{f}}($ W51, Kilaarsarfik) } \\
\hline 1143 & KAL0929 & M, 35-40 & $1030 \pm 45$ & 1297 & $1275-1317$ & -14.8 & 73 \\
\hline 1145 & KAL0960 & $F, 40-45$ & $940 \pm 45$ & 1301 & $1282-1322$ & -16.2 & 57 \\
\hline 1147 & KAL0959 & $F, 40-45$ & $940 \pm 40$ & 1301 & $1284-1320$ & -16.2 & 57 \\
\hline 1148 & KAL0964 & F, 25-30 & $970 \pm 40$ & 1307 & $1290-1328$ & -15.4 & 66 \\
\hline 1146 & KAL0961 & F, 20-25 & $970 \pm 40$ & 1390 & $1323-1412$ & -14.1 & 81 \\
\hline 1144 & KAL0928 & F, 20-25 & $865 \pm 40$ & 1413 & $1393-1432$ & -15.2 & 68 \\
\hline
\end{tabular}

AAR-number refers to the AMS ${ }^{14} \mathrm{C}$ dating sample. Object ID-number is the registration number of the National Museum of Denmark, where available (followed by slash) and the registration number of the Copenhagen Anthropological Laboratory (KAL or CLA). Archaeological sites are given Norse names on the basis of an assumed identification with locations mentioned in Icelandic history writing and sagas. Site numbers and modern Greenlandic names are given in parentheses. $\mathrm{F}$ $=$ female, $\mathbf{M}=$ male, $\mathrm{u}=$ unknown sex. $\mathrm{B}=$ skeleton of bishop. Conventional ${ }^{14} \mathrm{C}$ ages were converted into calendar year by using a calibration curve interpolated between the terrestrial (tree-ring) curve and the model-calculated marine curve with the fraction of marine diet as an input parameter. The $\delta^{13} \mathrm{C}$ values are with respect to the VPDB standard; the uncertainty is $\pm 0.05 \%$ (at $1 \sigma$ ). The percentage of marine diet is calculated by linear interpolation between the end-point values $-12.5 \%$ (100\% marine) and $-21 \%$ ( $100 \%$ terrestrial). We estimate an uncertainty of $10 \%$ in the percentage value. Details of the samples and sample ID numbers may be found in Lynnerup 1998. The relevant excavations have been described in:

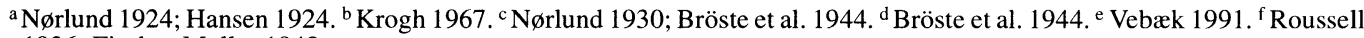
1936; Fischer-Møller 1942. 
The human bones display extreme variation in $\delta^{13} \mathrm{C}$ values ( -14.5 to $-19 \%$ VPDB) (Table 2), nearly spanning the full range between the marine and the terrestrial values of Table 1 . When the corresponding fraction of marine food consumed by each individual is calculated from the measured $\delta^{13} \mathrm{C}$ value by linear interpolation between the adopted endpoint values (see above), the values fall in the range of 20 to $80 \%$ marine diet (Table 2). Information on the marine reservoir effect as needed for the ${ }^{14} \mathrm{C}$ age calibration is available from recent model calculations of the damped response of the sea to the varying ${ }^{14} \mathrm{C}$ level in the atmosphere. We have used the global marine model by Stuiver, Pearson, and Braziunas (Stuiver et al. 1986), later revised (Stuiver and Braziunas 1993) and implemented (Stuiver and Reimer 1993) in the ${ }^{14} \mathrm{C}$ age calibration program CALIB 3.03. This program calculates the calibration curve valid for a given fraction of marine food by linear interpolation between the terrestrial tree-ring curve and the smoother marine curve calculated from a global model of the mixedlayer of the world ocean. The $100 \%$ marine curve used for interpolation is shifted relative to the standard curve by a constant, $\Delta \mathrm{R}\left({ }^{14} \mathrm{C}\right.$ years $)$, which accommodates the deviation in reservoir age of the local sea from that of the model world ocean, which varies in time around a value of $400 \mathrm{yr}$. The $\Delta \mathrm{R}$ value was determined in a calibration procedure by using 3 bone/cloth sample pairs, assumed to have pair-wise identical true age.

The first 6 samples in Table 2 represent these 3 skeletons (AAR-1271, -1269 and -1270) and their respective grave clothes (AAR-1290, -1289 and -1288) as excavated (in 1921) from a group of burials found in a corner of the churchyard at Herjolfsnes (Nørlund 1924). The bodies were positioned on top of each other, thus believed to be buried at nearly the same time. While the ${ }^{14} \mathrm{C}$ dates of the 3 cloth samples coincide within the measuring uncertainty, the dates of the bones at first sight showed a surprisingly large scatter (Figure 2). For example, skeleton AAR-1269, a young woman, was 420 ${ }^{14} \mathrm{C}$ years older than her grave clothes. This apparent age difference is explained by the marine reservoir effect, since the $\delta^{13} \mathrm{C}$ value of her bone showed that her average food during the approximately 10-yr turnover time of carbon had been highly marine (78\%), while the woolen clothes are expected to be purely terrestrial. In fact, this assumption is confirmed by the narrow distribution of the measured $\delta^{13} \mathrm{C}$ values around an average of $-22.2 \pm 0.2 \%$ VPDB for the 6 textiles, as hair and wool is expected to be approximately $1 \%$ o more negative in $\delta^{13} \mathrm{C}$ than bone collagen (Vogel et al. 1978; van der Merwe 1989). Thus, we see no sign of seaweed feeding of sheep (see below) in this case and, with 1 exception (see below), the cloth dates are also consistent with the archaeological dating (Arneborg 1996).

These 3 textile samples are therefore ideally suited to fix the reservoir correction parameter $\Delta R$, especially since 1 of the associated bone samples (AAR-1269) is close to the maximum marine component found in the sample set. Since bone and cloth must have practically the same true age (the turnover time of carbon in the bone is assumed to match approximately the lifetime of the cloth), it is necessary to adjust the $\Delta \mathrm{R}$ value of the marine calibration curve for each of the 3 bone dates until the calibrated ages coincide with that of the textile. The analysis is illustrated in Figure 2. Identical $\Delta \mathrm{R}$ values of $+50 \mathrm{yr}$ were obtained for all 3 bone/cloth pairs, in spite of the fact that the marine fractions of the bones differ greatly. This is a crucial point that strongly supports the validity of the reservoir correction in the calibration procedure. The displacement is $\Delta \mathrm{R}=50 \mathrm{yr}$, corresponding to a reservoir age varying between 400 and $500{ }^{14} \mathrm{C}$ yr for the time range shown. Another important check on the calibration procedure is the continuation of the shifted curve to the period AD 18001910, which gives values varying between 400 and 465 years. This is in good agreement with existing measurements of reservoir age for southern Greenland, all of which have been carried out on mollusks from the 19th and 20th century and yielded values in the range 400-550 yr depending on location. The fitted parameter $\Delta \mathrm{R}$ is coupled to the choice of $\delta^{13} \mathrm{C}$ endpoint values through the fix- 


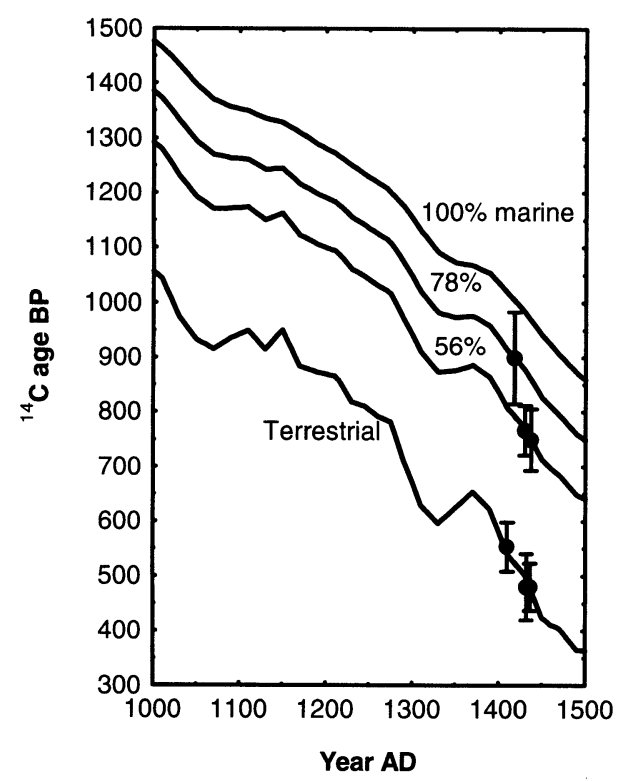

Figure $2{ }^{14} \mathrm{C}$ calibration curves. Terrestrial curve is based on tree-ring measurements (Stuiver and Braziunas 1993). Marine curve $(100 \%)$ is a model calculation for the mixed layer of the ocean (Stuiver and Braziunas 1993). Curves labelled $78 \%$ and $56 \%$ marine are interpolations. The data points are measured ${ }^{14} \mathrm{C}$ ages of 3 bone/cloth pairs from the Norse churchyard at Herjolfsnes, Greenland. The cloth data are plotted on the terrestrial curve. The $\delta^{13} \mathrm{C}$ of the bone samples showed marine fractions of $55 \%, 56 \%$, and $78 \%$. By assuming each bone/cloth pair to be of identical calendar age, the mixed-layer curve was adjusted by an upwards parallel shift to make the interpolated curves fit the bone data points. The displacement is $\Delta \mathrm{R}=50 \mathrm{yr}$, corresponding to a reservoir age varying between 400 and $500{ }^{14} \mathrm{C}$ yr for the time range shown.

points provided by the textile dates, which make the resulting calibrated ${ }^{14} \mathrm{C}$ ages rather insensitive to the chosen endpoints.

We conclude from the above that it is reasonable to use marine calibration curves thus obtained to derive calendar ages for the whole time period studied in this work (Table 2). All calendar ages are consistent with archaeological information. In the following we discuss the ages for 4 selected burial groups in relation to independent information.

\section{DISCUSSION OF ${ }^{14} \mathrm{C}$ DATES}

According to archaeological dates, the oldest Norse bones were found at Erik the Red's farm Brattahlið in the churchyard of the so-called Tjodhilde's Church (cf. Krogh 1967; also Table 2 and Figure 3). The date of an ox-bone fragment (purely terrestrial) found in a mass grave proved that the Norse people and their cattle were present at Brattahlið at precisely the time (AD 985) mentioned in the Icelandic sagas for Norse arrival (landnam). Two of the human bones, a male and a female (AAR-1275 and AAR-1571), yielded similar old ages, but only after the marine correction was applied. Without the marine correction the skeletons would have antedated the arrival of Eric the Red (AD 985) by 100-200 yr, contradicting historical evidence. The human bones from Brattahlið were $20-50 \%$ marine. This scatter could be explained either by social differences in subsistence or by new immigration. Thus, low values are expected for people newly arrived from Iceland or Norway with a more terrestrial $\delta^{13} \mathrm{C}$ imprinted in their bones. The youngest bone dates from Brattahlið (AD 1100-1200) have large uncertainties associated with them due to a plateau in the calibration curve (see Figure 2).

According to an account on the Nordic settlements in Greenland from the second half of the 14th century (Ivar Barðarsson's Greenland Description in Jónsson 1930), the Western Settlement was abandoned in the middle of the 14th century. From that area, we have dated 6 skeletons from the churchyard at the farm Sandnes. The skeletons were found (in 1930) in a stratigraphic sequence on top of each other, presumably buried almost simultaneously (Roussell 1936). The graves were situ- 
ated west of the church in an area that became part of the churchyard at a late date in the history of the site. The calibrated ${ }^{14} \mathrm{C}$ dates of the skeletons, having high, but different, marine food fractions, do not contradict the written record, but some of the uncertainties are quite large. The dates of the 5 lowest-lying skeletons (first 5 in Table 2, Sandnes) cluster around AD 1300.

The Norse ruins at Igaliku have been identified with Garðar, the residence of Greenland's bishop (Nørlund 1930). The skeleton (AAR-1439) of a bishop (buried with his crosier) was found in the north chapel of the church ruins. Directly below the bishop lay the skeletons (AAR-1437 and AAR-1438) of a male and a female side by side. The bones of the bishop were only $25 \%$ marine, perhaps indicating that he had arrived a short time before from Norway where all the bishops of Greenland originated (Arneborg 1990). The low marine content of the bishop's food could also be explained by his high social status, presumably allowing access to beef and game. The bones of the male and female skeletons had considerably higher marine food fractions, 50 and $40 \%$, respectively. We note that the marine corrections, although widely different, lead to coinciding calibrated ages for the 3 skeletons from Garðar.

An independent means of dating the skeletons relies on analysis of the arranged arm-position of the buried person, a method applicable to dating graves in Scandinavia (e.g., Redin 1976, Kieffer-Olsen 1993). Though the relative development of the positions of the arms (A: arms along the side; B: hands over pelvis; $\mathrm{C}$ : lower arms parallel over stomach; and D: hands over chest) have been more or less accepted, the absolute dates are still debated. In a work that involved graves from 8 churchyards in medieval Denmark (including Scania in South Sweden and Slesvig in Northern Germany), Kieffer-Olsen (1993) concluded that arm position A dominated until ca. AD 1250, arm position B dominated ca. 1250-1350 and arm position $C$ dominated from ca. 1350 until the mid-fifteenth century, after which arm position D became the most common. Evidently Norse Greenland graves follow the described relative development of arm positions (for more details, see Lynnerup 1998, p 55 ff); still, it would not be reasonable uncritically to apply South Scandinavian chronology to the Norse Greenland situation. Nevertheless, we note that the 3 dead persons in the north chapel of the Garðar church (E47) (Nørlund 1930) were buried with their arms in position B (ca. AD 1250-1350), which is consistent with the calibrated ages for the 3 skeletons (AAR-1437, AAR-1439 and AAR-1438). Similarly at the convent in Narsarsuaq (E149) (Vebæk 1991), the arm position B (ca. AD 1250-1350) is represented in 2 cases (AAR-1265 and AAR-1264), and arm position C (ca. AD 135-1450) likewise in the 2 other cases (AAR-1266 and AAR-1263).

We conclude from this discussion that the pattern of ${ }^{14} \mathrm{C}$ dates for bones of mixed marine/terrestrial origin is consistent with other age evidence. We observe repeatedly that groups of skeletons, which are likely to have been buried at the same time, come out with identical calibrated ${ }^{14} \mathrm{C}$ ages (within experimental uncertainty) even in cases where the marine reservoir corrections differ markedly. We also observe accordance between the archaeological dates and the calibrated ${ }^{14} \mathrm{C}$ ages. It thus appears that mixed marine bone samples can be reliably dated with reservoir corrections based on measured collagen $\delta^{13} \mathrm{C}$ values.

Greenland may constitute a particularly simple system in this respect due to the absence of calcareous freshwater sources, which are known to produce high local reservoir effects of more than 1000 yr, for example at Dutch sites (Lanting and van der Plicht 1996) and Danish fjords (Heier-Nielsen et al. 1995). Norse Greenland sheep and cattle may have had a small marine component from seaweed and fish refuse, as shown for recent times in Norway (Høegh 1982) and Iceland (Kristjánsson 1982). Because the corresponding ${ }^{13} \mathrm{C}$ isotope value will be passed on to the consumer, the reservoir correction procedure will still be valid. Questions remain about the effect of the high variability in, for 
example, Greenland seal bone $\delta^{13} \mathrm{C}$ values, often "less marine" than the Eskimos in Table 1, observed from measurements in our own laboratory and reported by other authors (e.g. Tauber 1984). If these values in bone collagen reflect anomalous $\delta^{13} \mathrm{C}$ values in seal meat consumed by humans under study, it could lead to errors in evaluated marine food fractions. A similar ambiguity in the calculation of human marine fractions could result from observed slightly "marine" $\delta^{13} \mathrm{C}$ signals, which we have observed in Greenland reindeer bones (cf. Tauber 1984), unless this turns out to be due to consumption of seaweed. Clarification of these details will be gained by more extensive isotopic measurements on archaeological bone samples of the domestic animals and game consumed by the Norse.

The $\delta^{13} \mathrm{C}$ in bone collagen mainly reflects the ${ }^{13} \mathrm{C}$ composition of the protein in the diet (Ambrose and Norr 1993), while bone apatite values may be more representative of the whole diet (see also Lanting and van der Plicht 1996). In the present study, the protein dietary composition may well be representative of the whole diet, as both the marine and terrestrial food resources of the Norse must have been very protein-rich. Since the Greenland climate did not allow cultivation of grain and vegetables, the terrestrial diet of the Norse was limited to meat and dairy products. We therefore interpret the $\delta^{13} \mathrm{C}$ variability in human bone collagen discussed in the following section as being directly representative of real differences in subsistence patterns.

\section{NORSE CHRONOLOGY AND DIET}

Five sample dates help us to establish the main chronological framework of the Norse in Greenland, even without relying on the reservoir correction procedure or archaeological dating. The ox bone from Brattahlið (AAR-1273) and the 3 burial textiles from Herjolfsnes (AAR-1288, -1289, -1290) establish the presence of Norse colonies in Greenland from around AD 1000 to the first half of the 15th century (AD $1430 \pm 15$ ), in other words slightly later than the last written historical evidence (a wedding in 1408). Arguments based on stylistic evidence from the "Burgundy Cap" for Norse presence after AD 1500 have been refuted by the ${ }^{14} \mathrm{C}$ date (AAR-2201, Table 2) on the cap that places it in the 14th century (see Arneborg 1996).

The detailed chronology established by the ${ }^{14} \mathrm{C}$ dates of Viking bones allows us to assess whether the large variation in marine food consumption may show a temporal pattern. The plot (Figure 3) of $\delta^{13} \mathrm{C}$ values, the proxy for marine food fraction, versus calibrated ${ }^{14} \mathrm{C}$ age reveals that the average diet of the Norse people changed from $20 \%$ marine to $80 \%$ marine during the approximately 500 years that the settlement lasted. This trend, if representative of the Greenland Norse population as a whole, shows a marked shift in Norse diet from the initial settlement period to the period of depopulation. The Norse colonists adapted to marine food resources, although at $80 \%$ not quite to the extent of contemporaneous Eskimos.

The marine element should derive first and foremost from seal according to the animal bone assemblages found in middens in Greenland Norse settlements. Fish bones are nearly absent in the collections. This may, however, be explained by taphonomic biases such as the well-known poor preservation of fish bone and its appeal as a food source to both birds and domestic animals like dogs. It is hard to believe that the Greenland Norse did not tap the very rich resources of fish in the fjords, as did their relatives all over the North Atlantic and in Norway. Future isotope research may shed light on the extent to which fish actually formed part of the Greenland Norse diet.

The present study has provided a chronology and direct evidence for dramatic changes in the lives of the Norse in Greenland. The reason for the change may be deteriorating climate, which several authors have discussed as the main reason for the decline in population of the Norse settlements (e.g. 


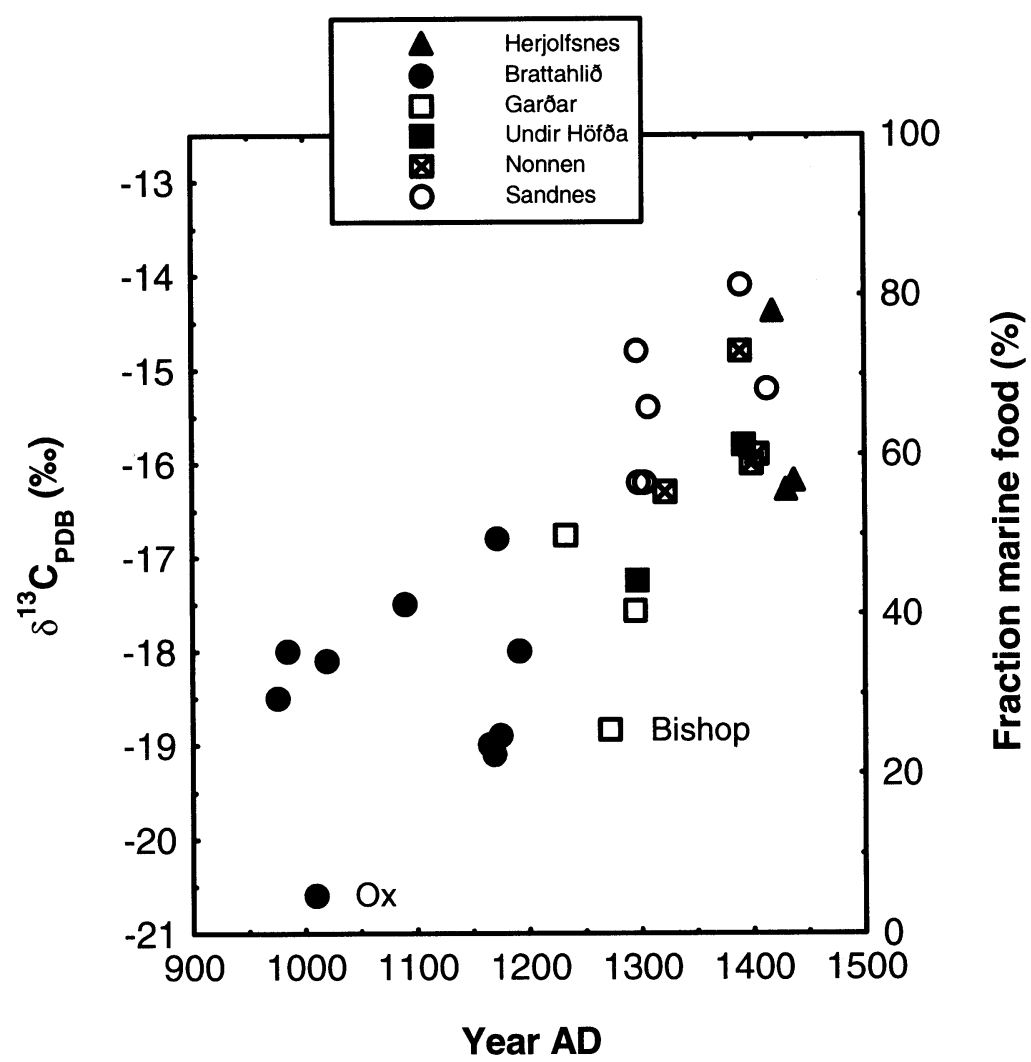

Figure 3 Measured $\delta^{13} \mathrm{C}$ versus calendar year for Norse skeletons from Greenland. Symbols refer to churchyards. Sandnes is in the Western Settlement, the others are in the Eastern Settlement. Right-side ordinate axis is the marine food fraction calculated from $\delta^{13} \mathrm{C}$. The scatter in $\delta^{13} \mathrm{C}$ is due to real differences in diet of individuals. Note the terrestrial value for the ox bone. High social status or recent arrival from Norway could explain the low marine diet of the bishop buried in the Garðar cathedral.

Stuiver et al. 1995; Barlow et al. 1997; Lynnerup 1998; see also Fricke et al. 1995). Recently, Greenland ice-sheet temperature data have been used for a climatic reconstruction, which is specific for the high-latitude North Atlantic region (Dahl-Jensen et al. 1998). The results indicate a steady decrease from a temperature maximum around AD 1000 to a minimum around AD 1500, which may have gradually forced the Greenland Norse to change their subsistence pattern.

\section{ACKNOWLEDGMENTS}

We acknowledge the skillful laboratory assistance of Vibeke Jensen (AMS Laboratory) in preparing the samples and graphite targets and also that of Guðbjörg Aradóttir (Science Institute) in operating the mass spectrometer for $\delta^{13} \mathrm{C}$ measurements. We thank Egon Jans for his invaluable assistance in maintaining the ion sources and the tandem accelerator. Tinna Møbjerg has kindly let us use the ${ }^{14} \mathrm{C}$ and $\delta^{13} \mathrm{C}$ results measured by us on a series of Greenland Eskimo bones, submitted and funded by her as part of a separate research program. 
The AMS Laboratory is financially supported by the Danish Natural Science Research Council. For the ${ }^{14} \mathrm{C}$ dates and $\delta^{13} \mathrm{C}$ measurements we gratefully acknowledge support from the following funds: Queen Margrethe and Prince Henrik's foundation, Regensburg's grant, the Augustinus Foundation, the Novo Nordic Foundation, Aase and Jørgen Münter's Foundation.

\section{REFERENCES}

Ambrose SH, Norr L. 1993. Experimental evidence for the relationship of the carbon isotope ratios of whole diet and dietary protein to those of bone collagen and carbonate. In: Lambert JB, Grupe G, editors. Prehistoric Human Bone. Berlin: Springer-Verlag. p 1-37.

Arneborg J. 1990. The Roman Church in Norse Greenland. Acta Archaeologica 61:142-50.

Arneborg J. 1996. Burgunderhuer, baskere og døde nordboer i Herjolfsnæs, Grønland (Burgundian caps, Basques and dead Norsemen at Herjolfsnes, Greenland). English summary. Nationalmuseets Arbejdsmark 1996. Copenhagen: Nationalmuseet. p 75-83.

Barlow LK, Sadler JP, Ogilvie AEJ, Buckland PC, Amorosi T, Ingimundarson JH, Skidmore P, Dugmore AJ, McGovern TH. 1997. Interdisciplinary investigations of the end of the Norse Western Settlement in Greenland. The Holocene 7:489-99.

Brown TA, Nelson DE, Vogel JS, Southon JR. 1988. Improved collagen extraction by modified Longin method. Radiocarbon 30(2):171-7.

Bröste K, Fischer-Møller K, Pedersen PO. 1944. The mediaeval Norsemen at Gardar. Meddelelser om Grønland 89(3): 1-62.

Chisholm BS. 1989. Variation in diet reconstructions based on stable carbon isotopic evidence. In: Price TD, editor. The Chemistry of Prehistoric Human Bone. Cambridge: Cambridge University Press. p 1037.

Chisholm BS, Nelson DE, Schwarcz HP. 1982. Stable carbon isotope ratios as a measure of marine versus terrestrial protein in ancient diets. Science 216:11312.

Chisholm BS, Nelson DE, Schwarcz HP. 1983. Marine and terrestrial protein in prehistoric diets on the British Columbia coast. Current Anthropology 24:396-8.

Dahl-Jensen D, Mosegaard K, Gundestrup N, Clow GD, Johnsen SJ, Hansen AW, Balling N. 1998. Past temperatures directly from the Greenland ice sheet. Science 282:268-71.

Fischer-Møller K. 1942. The mediaeval Norse settlements in Greenland. Meddelelser om Grønland 89(2): $1-82$.

Fricke HC, O'Niel JR, Lynnerup N. 1995. Oxygen isotope composition of human tooth enamel from medieval Greenland: linking climate and society. Geology 23:869-72.

Grummesgaard-Nielsen S. 1997. Thulekulturens grave. Grønland 5-7:198-227.

Gulliksen S, Scott M. 1995. Report of the TIRI workshop. Radiocarbon 37:820-1.
Hansen FCC. 1924. Anthropologia medico-historica Groenlandiae antiquae. I. Herjolfsnes. Meddelelser om Grønland 67:291-547.

Hedges REM, van Klinken GJ. 1992. A review of current approaches in the pretreatment of bone for radiocarbon dating by AMS. Radiocarbon 34(3):279-91.

Heier-Nielsen S, Heinemeier J, Nielsen HL, Rud N. 1995. Recent reservoir ages for Danish fjords and marine waters. Radiocarbon 37(3):875-82.

Heinemeier J, Rud N. 1997. Kulstof-14 datering med acceleratormetoden (AMS). Grønland 5-7:232-8.

Høegh OA. 1982. Tang I, Norge. Kulturhistorisk Leksikon for Nordisk Middelalder 18:124-8.

Johansen OS, Gulliksen S, Nydal R. 1986. $\delta^{13} \mathrm{C}$ and diet: analysis of Norwegian human skeletons. Radiocarbon 28:754-61.

Jones G. 1986. The Norse Atlantic Saga. New York: Oxford University Press. 337 p.

Jónsson F. 1930. Det gamle Grønlands beskrivelse af Ívar Bárðarson. Copenhagen: Levin \& Munksgaard. $75 \mathrm{p}$.

Kieffer-Olsen J. 1993. Grav og gravskik i det middelalderlige Danmark. Afdeling for Middelalder-arkaologi og Middelalder-arkacologisk Nyhedsbrev (Aarhus University):1-212.

Kristjánsson L. 1982. Tang I, Island. Kulturhistorisk Leksikon for Nordisk Middelalder 18:128-30.

Krogh KJ. 1967. Viking Greenland. Copenhagen: The National Museum. 182 p.

Lanting JN, Van der Plicht J. 1996. Wat hebben Floris V, skelet swifterbant S2 en visotters gemeen? [resumé in English]. Palaeohistoria 37/38:491-519.

Lidén, K, Nelson DE. 1994. Stable-carbon isotopes as dietary indicator in the Baltic area. Fornvännen 89:1421.

Longin R. 1971. New method of collagen extraction for radiocarbon dating. Nature 230:241-2.

Lovell NC, Nelson DE, Schwarcz HP. 1986. Carbon isotope ratios in paleodiet: lack of age or sex effect. $A r$ chaeometry 28:51-5.

Lynnerup N. 1998. The Greenland Norse - a biologicalanthropological study. Meddelelser om Grønland Man \& Society 24:1-149.

Lynnerup N, Brings Jacobsen JC, Thorsen C, Kludt T. 1997. Menneskeknoglerne fra gravene ved Asummiut. Grønland 5-7:227-32.

Nørlund P. 1924. Buried Norsemen at Herjolfsnes. Meddelelser om Grønland 67:1-270.

Nørlund P. 1930. Norse ruins at Gardar. Meddelelser om Grønland 76:1-170. 
Redin L. 1970. Lagmanshejdan: ett gravfelt som spegling av sociala strukturer i Skanør. Acta archaeologica Lundensia 10:1-201.

Renfrew C, Bahn P. 1991. Archaeology: Theory, methods and practice. London: Thames and Hudson. $543 \mathrm{p}$.

Roussell, Aa. 1936. Sandnes and the neighbouring farms. Meddelelser om Grønland 88(2):1-219.

Stuiver M, Braziunas TF. 1993. Modeling atmospheric ${ }^{14} \mathrm{C}$ influences and ${ }^{14} \mathrm{C}$ ages of marine samples to 10,000 BC. Radiocarbon 35(1):137-90.

Stuiver M, Grootes PM, Braziunas T. 1995. The GISP2 $\delta^{18} \mathrm{O}$ climate record of the past 16,500 years and the role of the sun, ocean, and volcanoes. Quaternary Research 44:341-54.

Stuiver M, Polach HA. 1977. Discussion: reporting ${ }^{14} \mathrm{C}$ data. Radiocarbon 19(3):355-63.

Stuiver M, Pearson GW, Braziunas T. 1986. Radiocarbon age calibration of marine samples back to $9000 \mathrm{cal} \mathrm{yr}$ BP. Radiocarbon 28(2B):980-1021.

Stuiver M, Reimer PJ. 1993. Extended ${ }^{14} \mathrm{C}$ data base and revised CALIB $3.0^{14} \mathrm{C}$ age calibration program. $R a$ diocarbon 35:215-30.

Tauber H. $1981 .{ }^{13} \mathrm{C}$ evidence for dietary habits of pre- historic man in Denmark. Nature 292:332-3.

Tauber H. 1984. ${ }^{14} \mathrm{C}$ Dating of human beings in relation to dietary habits. In: Mook WG, Waterbolk HT, editors. Proceedings of the First International Symposium on ${ }^{14} \mathrm{C}$ and Archaeology. PACT 8. Strasbourg: Council of Europe. p 365-75.

Van der Merwe NJ. 1982. Carbon isotopes, photosynthesis, and archaeology. American Scientist 70:596-606.

Van der Merwe NJ. 1989. Natural variation in ${ }^{13} \mathrm{C}$ concentration and its effect on environmental reconstruction using ${ }^{13} \mathrm{C} /{ }^{12} \mathrm{C}$ ratios in animal bones. In: Price DT, editor. The chemistry of prehistoric human bone Cambridge: Cambridge University Press. p 105-25.

Van der Merwe NJ, Vogel JC. $1978 .{ }^{13} \mathrm{C}$ content of human collagen as a measure of prehistoric diet in Woodland North America. Nature 276:815-6.

Vebæk, CL. 1991. The church topography of the Eastern Settlement and the excavation of the Benedictine Convent Narsarsuaq in the Uunartoq Fjord. Meddelelser om Gronland - Man \& Society 14:1-81.

Vogel JC, Fulls A, Ellis RP. 1978. The geographical distribution of Kranz grass in South Africa. South African Journal of Science 74:209-15. 